\title{
EVALUATION OF THE PROSPECTS FOR PRELIMINARY COOLING OF NATURAL GAS ON MAIN PIPELINES BEFORE COMPRESSION THROUGH THE DISCHARGE OF EXHAUST HEAT OF GAS-TURBINE UNITS
}

\author{
Oleksandr Titlov ${ }^{l}$ \\ titlov1959@gmail.com \\ Oleg Vasyliv ${ }^{l}$ \\ oleg_vas@ukr.net \\ Tetiana Sahala \\ sgltt@rambler.ru \\ Nataliia Bilenko ${ }^{1}$ \\ natalibilenco@gmail.com \\ ${ }^{1}$ Department of Heat-and-Power Engineering and Fuel Pipeline Transportation \\ Odessa National Academy of Food Technologies \\ 1/3 Dvoryanska str., Odessa, Ukraine, 65082
}

\begin{abstract}
For the transportation of natural gas through pipelines, gas pumping units (GPU) are installed at numerous compressor stations (CS), the energy carrier for which, in most cases, is transported natural gas. $0.5 \ldots 1.5 \%$ of the volume of transported gas is consumed (burned) by the pumping unit drive.

The situation with the replacement of existing equipment with modern equipment is associated with significant investments, on the one hand, and the uncertainty with the transit of Russian natural gas through gas transmission systems of Ukraine in the near future. More promising is the way to increase the efficiency of the GPU cycle through the use of circuits with preliminary cooling of the compressed gas.

The aim of this research is studying the prospects for the application of technology for pre-cooling technological natural gas before compression in a gas pumping unit based on heat-using absorption refrigeration machines.

To analyze the effect of pre-cooling of technological natural gas on the compressor stations of main gas pipelines, gas pumping units - GTK-10I were selected.

The calculation of GPU power consumption and fuel gas consumption at various temperatures of the process gas at the inlet to the supercharger was performed.

The calculation of the operating parameters of the gas pumping unit is performed and the energy and financial prospects of the technology for cooling the process gas before compression in the GPU CS are shown. For the current economic situation (July 2019) in the Ukrainian gas market, the daily decrease in operating costs in standard gas pipelines with a decrease in gas temperature before compression in the gas pumping unit by $20 \mathrm{~K}$ ranges from 1800 USD to 3360 USD.

A scheme of a recycling plant based on absorption water-ammonia refrigeration machine (AWRM) is proposed, which in the range of initial data allows to reduce the temperature of technological natural gas before compression by $11 \ldots 13{ }^{\circ} \mathrm{C}$.

Keywords: main pipelines, gas pumping units, natural gas cooling before compression, absorption water-ammonia refrigeration machine.
\end{abstract}

DOI: $10.21303 / 2461-4262.2019 .00978$

\section{Introduction}

The gas transportation system of Ukraine consists of a dense network of gas communications, which serve to supply gas to both domestic consumers and to transit fuel to the countries of Western Europe. For the transportation of natural gas through pipelines, gas pumping units (GPU) are installed at numerous compressor stations (CS), the energy carrier for which, in most cases, is transported natural gas. $0.5 \ldots 1.5 \%$ of the volume of transported gas is spent (burned) on the pump- 
ing unit drive [1]. Therefore, the problem of minimizing fuel gas consumption in a gas pumping unit is relevant and requires careful analysis.

The efficiency of the majority of the GPU fleet currently in operation in Ukraine is in the range of $24 . . .27$ [2].

Pumping costs can be reduced as follows:

- replacement of existing units with low efficiency by more economical ones, with an efficiency of $36 \%$ and higher;

- modernization of existing equipment with the use of new approaches to the organization of the processes of compression (compression) at the main compressor stations.

The situation with the replacement of existing equipment with modern equipment is associated with significant investments, on the one hand, and the uncertainty with the transit of Russian natural gas through Ukrainian gas transportation systems in the near future [3, 4].

More promising is the way to increase the efficiency of the GPU cycle through the use of circuits with preliminary cooling of the compressed gas.

This position is based on the following.

If analyze the formula for the specific work of an ideal compressor $l$ for $1 \mathrm{~kg}$ of gas, it is possible to see that it is directly proportional to the absolute temperature of the gas before compression [5]

$$
l=\frac{R T_{1}}{K-1}\left[1-\left(\frac{P_{1}}{P_{2}}\right)^{\frac{K-1}{K}}\right]
$$

where $\mathrm{R}$ is the individual gas constant, $\mathrm{J} /(\mathrm{kg} \cdot \mathrm{K}) ; T_{1}$ - absolute gas temperature before compression, $\mathrm{K} ; K$ - the Poisson's ratio; $P_{1}$ and $P_{2}$ - the absolute gas pressure, respectively, before (at suction) and after compression, $\mathrm{Pa}$.

Since the value of the suction temperature is close in most cases to $\mathrm{T}=300 \mathrm{~K}$, from equation (1) it is possible to conclude that with a decrease in the temperature of the suction gas by $1{ }^{\circ} \mathrm{C}$, the work spent on compression of $1 \mathrm{~kg}$ of gas decreases by approximately $0,33 \%$ Thus, a decrease in the temperature of the gas before compression by $3{ }^{\circ} \mathrm{C}$ leads to a decrease in the work required to compress and move $1 \mathrm{~kg}$ of gas by approximately $1 \%$.

In a first approximation, this conclusion, obtained for an ideal compressor, can be applied to a real compressor [5].

The thermodynamic efficiency of diesel engines is also significantly affected by the temperature of charge air. With its increase by $10{ }^{\circ} \mathrm{C}$, the effective efficiency decreases by about $0.5 \%$ and, accordingly, the specific fuel consumption increases [6].

To reduce the temperature of the charge air, it is proposed to use one [7] and two-threestage [8] heat-utilizing steam-ejection refrigerating machine on a low-boiling working fluid (R142b). It is assumed that cooling systems [7, 8] utilize the heat of exhaust gases of combustion products.

The disadvantages of a cooling system based on steam ejection systems include the lowest energy efficiency among heat-using cooling systems and a critical dependence on changes in temperature of heating and cooling media [9].

The authors of [10] came to a similar conclusion when comparing the steam ejection and absorption refrigeration cycle.

If compare the absorption heaters using absorption water-ammonia refrigeration machine (AWRM) will have an advantage over lithium bromide (ALRM) in terms of the range of cooling temperatures. Thus, the minimum real cooling temperatures in the ALRM are not lower than $0{ }^{\circ} \mathrm{C}$ [11], and as the authors of [12] note, their decrease below $0{ }^{\circ} \mathrm{C}$ is theoretically possible, but difficult to achieve in practice.

The operating range of the AWRM at the lower boundary is $-45 \ldots-25{ }^{\circ} \mathrm{C}[13]$ and these systems, first of all, can find application in pre-cooling systems before compression of natural gas in the gas pumping unit. 
Currently, the experience or theoretical analysis of the use of both AWRM and ALRM as part of the CS of natural gas main pipelines is unknown.

The aim of research is studying the prospects for the application of technology for pre-cooling technological natural gas before compression in a gas pumping unit based on heat-using absorption refrigeration machines.

To do this, first of all, it is necessary to assess the effect of the temperatures of technological natural gas on suction on energy consumption in gas pumping units.

\section{Evaluation of the influence of the temperatures of process natural gas on suction on energy consumption in gas pumping units}

To analyze the effect of pre-cooling of process natural gas on the gas main pipelines, the following initial data were adopted:

- gas pumping units - GTK-10I;

- the number of working gas pumping units $2+1$ ( 2 in operation, 1 in reserve);

- supercharger - RF 2BB-30;

- nominal discharge of the supercharger $-16.5 \mathrm{mln} . \mathrm{m}^{3} / \mathrm{day}$;

- rated power - $10000 \mathrm{~kW}$;

- revolutions of the power shaft $-6200 \mathrm{rpm}$;

- pressure at the inlet to the compressor station - 3.8 $\mathrm{MPa}$;

- pressure at the outlet of the compressor station - 5.4 MPa;

- composition of natural gas meets the requirements of the Code of the gas transmission system, approved by the Decree of the National Commission of Ukraine, which carries out state regulation in the fields of energy and utilities [14].

Calculations are carried out in the following sequence according to the procedure [1].

The available power of the gas turbine drive of the CS GPU is determined as follows:

$$
N_{e}^{p}=N_{e}^{n} K_{N} K_{a i} K_{r}\left(1-K_{t} \frac{T_{g}-T_{g}^{n}}{T_{g}}\right) \frac{P_{a}}{0.1013}
$$

where $N_{e}^{n}$ - rated power of the gas turbine unit, $\mathrm{kW} ; K_{N}$ - coefficient taking into account the tolerances and condition of the gas turbine installation; $K_{a i}$ - coefficient taking into account the influence of the anti-icing system; $K_{r}$ - coefficient taking into account the influence of the exhaust heat recovery system; $K_{t}$ - coefficient taking into account the influence of ambient temperature; $T_{g}^{n}$ - nominal air temperature at the inlet to the gas turbine unit, $\mathrm{K} ; T_{g}$ - estimated air temperature at the inlet to the gas turbine unit, $\mathrm{K} ; P_{a}$ - design pressure of the outdoor air, which depends on the geodetic mark of the location of the compressor shop, MPa.

Next, the operating mode of the gas pumping unit is calculated using the gas-dynamic characteristics of the superchargers (Fig. 1) and their mathematical models [15].

Calculations of the operating mode of the compressor are performed using a computer program:

- the degree of increase in gas pressure is determined, provided that the relative frequency of rotation of the rotor of the supercharger is equal to unity, $\varepsilon_{s}$;

- polytropic efficiency $\eta_{p o l}$;

- reduced relative internal supercharger power $\left(\frac{N_{i}}{\rho_{\text {in }}}\right)_{r}$.

Then, using the similarity theorem of the operating modes of centrifugal machines, the degree of pressure increase is adjusted for values of the relative rotational speed of the supercharger rotor that are different from unity

$$
\varepsilon=\left[\left(\frac{n}{n_{n}}\right)_{r}^{2}\left(\varepsilon_{n}^{\frac{k-1}{k \eta_{p o l}}}-1\right)+1\right]^{\frac{k \eta_{p o l}}{k-1}}
$$


where $n$ - rotor speed of the supercharger; $n_{n}$ - the nominal rotor speed of the supercharger; $k$-adiabatic coefficient.

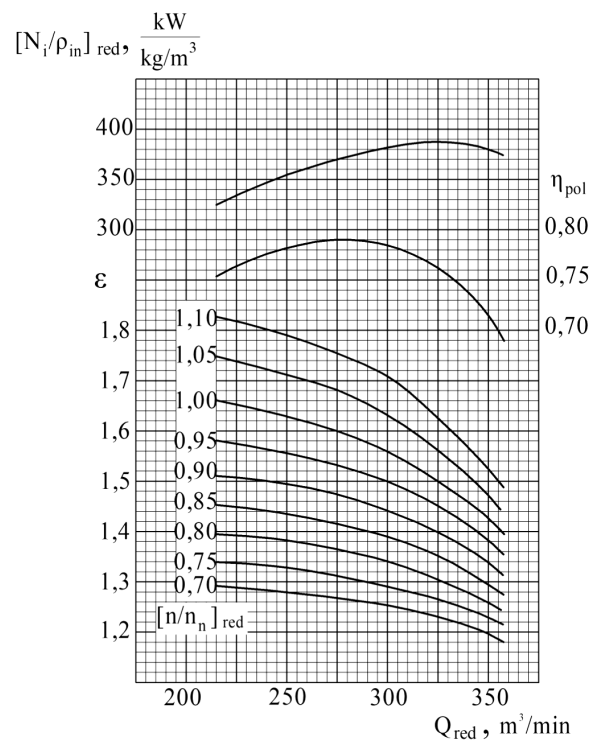

Fig. 1. The gas-dynamic characteristics of the RF 2BB-30 supercharger manufactured by Cooper Bessemer

Calculation of the operating mode of the compressor is performed by the iteration method in terms of speed.

The parameters of the operating mode of the compressor calculated for each iteration should be checked for the following technological limitations:

- gas pressure at the discharge must not exceed the permissible value based on the strength conditions;

- reduced performance of the supercharger in the input conditions must be at least the minimum value that ensures the operation of the supercharger without surging;

- reduced performance of the supercharger in the input conditions should not exceed the maximum value that ensures the normal operation of the supercharger; lation;

- power consumption should not be more than the available power of the gas turbine instal-

- relative frequency of rotation of the rotor of the supercharger should be at least the minimum acceptable value.

The internal indicator power $N_{i}$ and the power consumption $N$ of the supercharger are determined by the formulas

$$
\begin{gathered}
N_{i}=\left(\frac{N_{i}}{\rho_{\text {in }}}\right)_{r} \rho_{i n}\left(\frac{n}{n_{n}}\right)^{3}, \\
N=\frac{N_{i}}{\eta_{m} 0.95},
\end{gathered}
$$

where $\rho_{\text {in }}$ - the gas density under the conditions of entry into the supercharger, $\mathrm{kg} / \mathrm{m}^{3} ; \eta_{m}-$ mechanical efficiency of the supercharger.

The next step is the calculation of fuel gas consumption under standard conditions.

For one working GPU is performed according to the formula

$$
q_{t g}=q_{t g}^{n}\left(0.75 \frac{N}{N_{e}^{n}}+0.25 \sqrt{\frac{T_{g} P_{a}}{T_{g}^{n} 0.1013}}\right) \frac{Q_{c v}^{n}}{Q_{c v}},
$$


where $q_{t g}^{n}$ - the nominal flow rate of the process gas, million $\mathrm{m}^{3} /$ day; $N_{e}^{n}$ - rated power of a gas turbine installation, $\mathrm{kW} ; Q_{c o}^{n}$ - standard value of the calorific value of gas, $\mathrm{kJ} / \mathrm{kg} ; Q_{c o}$-calorific value of this gas, $\mathrm{kJ} / \mathrm{kg}$.

The results of the calculation of the power consumption of the gas pumping and the consumption of process gas at various temperatures of the process gas at the inlet to the supercharger (Fig. 2, 3).

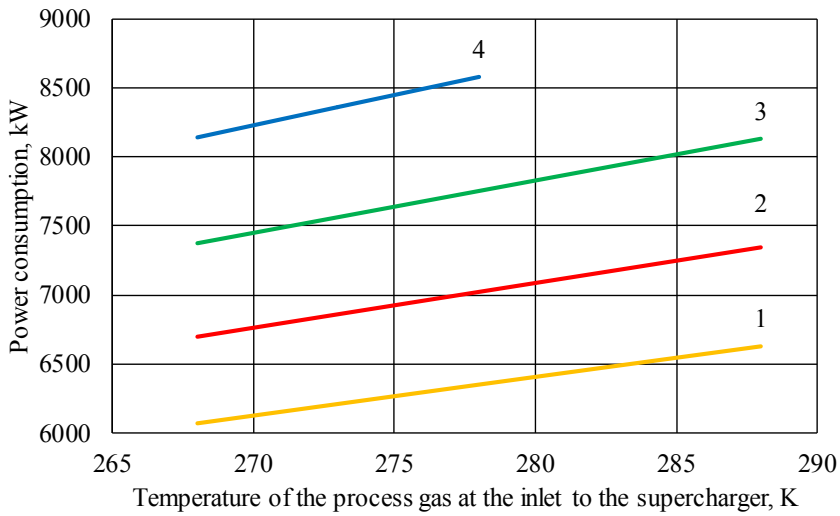

Fig. 2. Dependence of GPU power consumption on the temperature of the process gas before compression: process gas consumption $1-25$ million $\mathrm{m}^{3} / \mathrm{day}, 2-28$ million $\mathrm{m}^{3} / \mathrm{day}$, $3-31$ million $\mathrm{m}^{3} / \mathrm{day}, 4-34$ million $\mathrm{m}^{3} /$ day

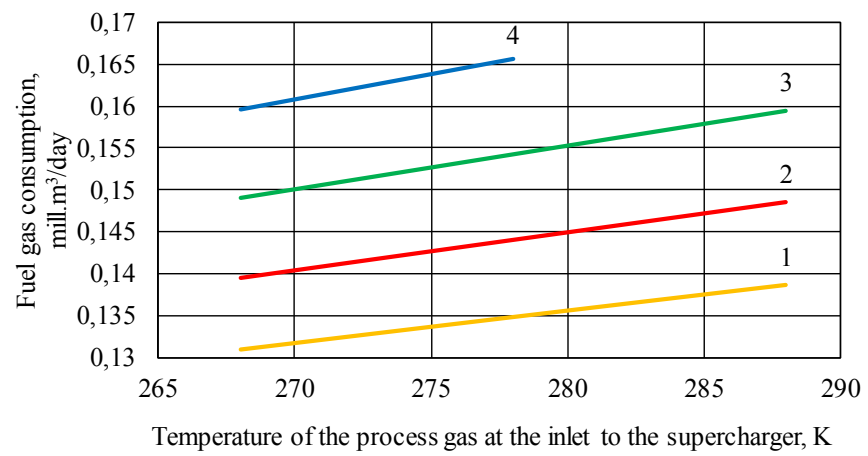

Fig. 3. Dependence of the fuel gas flow in the gas pumping unit on the temperature of the process gas before compression: the flow rate of the process gas is $1-25$ million $\mathrm{m}^{3} / \mathrm{day}$,

$2-28$ million $\mathrm{m}^{3} /$ day, $3-31$ million $\mathrm{m}^{3} /$ day, $4-34$ million $\mathrm{m}^{3} /$ day

The analysis given in Fig. 2, $\mathbf{3}$ of the results shows that when the temperature of the compressed process gas is reduced, the power of the gas pumping unit and, accordingly, the fuel gas consumption are reduced.

Thus, a decrease in the temperature of compressed process gas from $288 \mathrm{~K}\left(15^{\circ} \mathrm{C}\right)$ to $268 \mathrm{~K}$ (minus $5{ }^{\circ} \mathrm{C}$ ), the GPU power consumption is reduced by: $8.4 \%$ when transporting technological gas at 25 million $\mathrm{m}^{3} / \mathrm{day} ; 8.8 \%$ - at 28 million $\mathrm{m}^{3} / \mathrm{day} ; 9.3 \%$ - at 31 million $\mathrm{m}^{3} / \mathrm{day}$.

Reducing the temperature of compressed process gas from $278 \mathrm{~K}\left(5^{\circ} \mathrm{C}\right)$ to $268 \mathrm{~K}$ (minus $5{ }^{\circ} \mathrm{C}$ ), power consumption is reduced by $5.1 \%$ when transporting process gas 34 million $\mathrm{m}^{3} /$ day.

Lowering the temperature of the compressed process gas from $288 \mathrm{~K}\left(15^{\circ} \mathrm{C}\right)$ to $268 \mathrm{~K}$ (minus $5{ }^{\circ} \mathrm{C}$ ) allows to reduce fuel gas consumption by: $4.7 \%\left(0.007\right.$ million $\left.\mathrm{m}^{3} / \mathrm{day}\right)$ when transporting process gas 25 million $\mathrm{m}^{3} / \mathrm{day} ; 5.7 \%\left(0.009 \mathrm{million} \mathrm{m}^{3} / \mathrm{day}\right)$ - at $28 \mathrm{million} \mathrm{m}^{3} / \mathrm{day}$; $5.9 \%\left(0.010 \mathrm{million}^{3} / \mathrm{day}\right)$ - at 31 million $\mathrm{m}^{3} /$ day: $7.1 \%\left(0.013\right.$ million $\left.\mathrm{m}^{3} / \mathrm{day}\right)$ - at 34 million $\mathrm{m}^{3} /$ day. 


\section{Discussion of calculation results and development of promising schemes for pre-cooling systems of compressed technological natural gas}

Taking into account the obtained calculation results, it is possible to evaluate the economic effect of pre-cooling the process gas before compression in the gas pumping unit on the Ukrainian main pipelines.

Taking into account the current pricing policy of the Government of Ukraine - the cost of gas for industry in July 2019 is 6727 UAH (including VAT, but excluding transportation) for $1000 \mathrm{~m}^{3}$ [16], the daily economic effect will be: $47089 \mathrm{UAH}$ when transporting process gas at

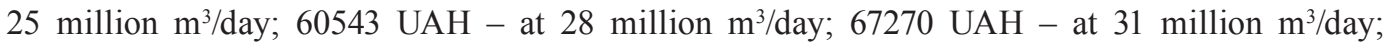
UAH 87451 - at 34 million $\mathrm{m}^{3} /$ day.

At the rate of $1 \$ \sim 26 \mathrm{UAH}$, the daily savings in our cases will be approximately: 1800 USD for the transportation of process gas - at 25 million $\mathrm{m}^{3} /$ day; $2,300 \mathrm{USD}$ - at $28 \mathrm{million} \mathrm{m}^{3} /$ day; 2580 USD - at 31 million $\mathrm{m}^{3} /$ day; 3360 - at 34 million $\mathrm{m}^{3} /$ day.

To estimate the temperature of the compressed gas after the GPU, let's use the formula for calculating the final temperature $T_{2}$ in the adiabatic compression process [5]

$$
T_{2}=\frac{T_{1}}{\left(\frac{P_{1}}{P_{2}}\right)^{\frac{K-1}{K}}},
$$

where $T_{1}$ - the absolute temperature of the gas before compression, $\mathrm{K} ; K$-Poisson's ratio (let's take $\mathrm{K}=1.3$ [5] for methane); $P_{1}=3.8 \mathrm{MPa}$ and $P_{2}=5.4 \mathrm{MPa}$ - for our design option, the absolute pressure of natural gas, respectively, before and after compression.

At the initial temperature during adiabatic compression, $\mathrm{T}_{1}=288 \mathrm{~K}\left(15^{\circ} \mathrm{C}\right)$, the final temperature will be $T_{2}=312 \mathrm{~K}\left(39^{\circ} \mathrm{C}\right)$; at $\mathrm{T}_{1}=283 \mathrm{~K}\left(10^{\circ} \mathrm{C}\right)$ the final temperature will be $T_{2}=307 \mathrm{~K}$ $\left(34{ }^{\circ} \mathrm{C}\right)$; at $\mathrm{T}_{1}=278 \mathrm{~K}\left(5^{\circ} \mathrm{C}\right)$ the final temperature will be $T_{2}=302 \mathrm{~K}\left(29^{\circ} \mathrm{C}\right)$; at $\mathrm{T}_{1}=273 \mathrm{~K}\left(0^{\circ} \mathrm{C}\right)$ the final temperature will be $T_{2}=296 \mathrm{~K}\left(23^{\circ} \mathrm{C}\right.$ ); at $\mathrm{T}_{1}=268 \mathrm{~K}$ (minus $5^{\circ} \mathrm{C}$ ) the final temperature will be $T_{2}=291 \mathrm{~K}\left(18^{\circ} \mathrm{C}\right)$.

The limiting temperature of natural gas after compression in a gas pumping unit is established on the basis of the thermal stability of bitumen coatings of gas pipelines and is $70{ }^{\circ} \mathrm{C}$ [1]. If the temperature of the gas at the outlet of the air cooling apparatus (ACA) rises to $45^{\circ} \mathrm{C}$, a warning signal and automatic activation of the ACA fans in reserve are provided.

In our case, the temperature level at the outlet of the gas pumping unit allows to turn off the ACA and get an additional economic effect that can be estimated for the specific climatic conditions of the region where the compressor station is located.

Taking into account the accepted initial data and the obtained calculation results, let's evaluate the technical feasibility of producing artificial cold by utilizing the heat of the GPU exhaust gases in a heat-using absorption refrigeration machine.

Given the wider range of cooling temperatures, let's dwell on the AWRM (Fig. 4).

Fig. 5 shows the AWRM scheme with two regenerative heat exchangers - solutions (RHS) and ammonia (RHA) [17].

The generator 1, which is filled with a liquid water-ammonia solution (WAS), is supplied with the thermal energy of the hot combustion products, as a result of which the low-boiling component (ammonia) with a certain amount of water vapor is mainly evaporated from the solution. The steam mixture enters the rectifier 2, in which it contacts the liquid WAS coming from the absorber 4. As a result of heat and mass transfer, less volatile water vapor partially condenses, increasing the concentration of ammonia in the steam stream.

Next, the WAS pairs enter the reflux condenser 3 with water cooling. It condenses the water vapor that remained in the steam stream after the rectifier 2.

The purified ammonia vapor enters the condenser 7, where it is liquefied with the removal of the heat of the phase transition. Liquid ammonia passes in RHA 8, in which it is cooled during heat exchange with a stream of cold ammonia vapor coming from the evaporator 9 to the absorber 4 . 


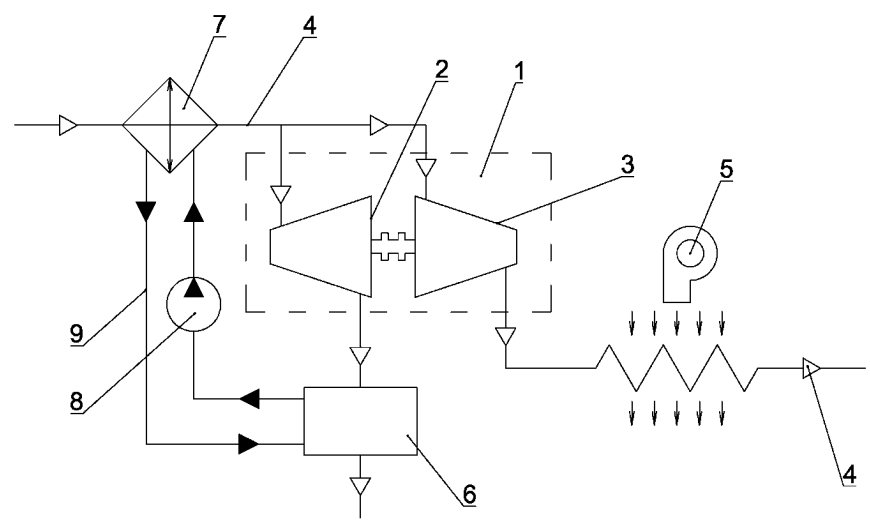

Fig. 4. Scheme of heat recovery of combustion products for cooling the process gas before compression: 1 - GPU; 2 - gas turbine drive (GTD); 3 - turbine; 4 - main gas pipeline; 5 - air cooling apparatus (ACA); 6 - AWRM; 7 - brine-natural gas heat exchanger;

8 - brine circulation pump; 9 - brine line

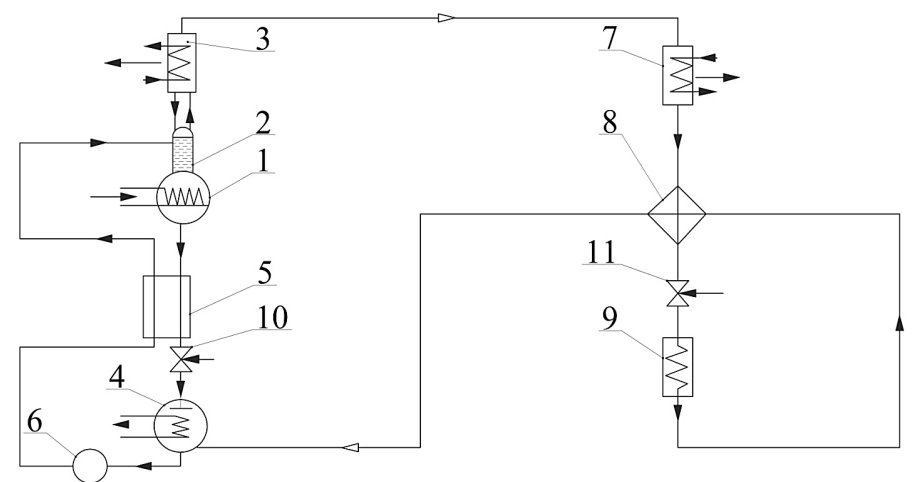

Fig. 5. AWRM scheme with two regenerative heat exchangers [17]: 1 - generator; 2 - rectifier; 3 - reflux condenser; 4 - absorber; 5 - RHS; 6 - circulation pump; 7 - condenser; 8 - RHA; 9 - evaporator; 10 - RV-1; $11-\mathrm{RV}-2$

The cooled liquid ammonia is throttled in RV-1 and boils in the evaporator 9 at low pressure and temperature with heat taken from the cooling object (in our case, from the brine stream).

The resulting ammonia vapor comes from the evaporator 9, through the RHA to the absorber 4, where it is absorbed and dissolved in a weak (with a minimum amount of ammonia) WAS.

In turn, a weak WAS through the reactor RV-2 enters from the generator 1 into the absorber 4 through RHS 5.

As a result of heat exchange in RHS 5, the weak AWS is cooled, and the strong (with the maximum amount of ammonia) AWS is heated and fed to the rectifier 2 by the circulation pump 6 .

Next, the AWRM cycle is repeated.

The presence of a rectifier and regenerative heat exchangers (RHS and RHA) in the AWRM circuit allows fairly simple methods to increase the energy efficiency of the refrigeration cycle [18].

At the first stage, let's evaluate the thermal power that can be obtained from the hot gas products of the gas pumping unit.

To do this, let's use the data of F. Sorogin [19] on the numerical values of temperatures and mass flow rates of exhaust gases depending on the power of a typical gas-turbine drive.

According to [19], for our power range from 6000 to $8500 \mathrm{~kW}$, the consumption of combustion products will be from 32 to $36 \mathrm{~kg} / \mathrm{s}$, and the temperature will be $710 \ldots 740^{\circ} \mathrm{C}$.

At the highest temperature in the AWRM generator, $140{ }^{\circ} \mathrm{C}$ [13], let's take the temperature of the exhaust gases $200{ }^{\circ} \mathrm{C}$. Then, for our data range, the available heat load from the combustion products in the AWRM generator will be from 19 to $22 \mathrm{~kW}$. 
Taking into account the numerical values of the heat coefficient AWRM 0.35...0.37, which takes into account losses with flue gases [20], a cooling capacity is $7.2 \ldots 8.5 \mathrm{~kW}$.

In this case, it is possible to reduce the temperature of the process gas before suction in the gas pumping unit by $11 \ldots 13^{\circ} \mathrm{C}$.

To increase the efficiency of the heat conversion process in the AWRM generator, it is possible to switch to a more complex, but also more energy-efficient AWRM scheme with deep heat recovery in the reflux condenser and rectifier [13].

When considering disposal issues, one must not lose sight of the importance of the dew point of water and hydrocarbons of natural gas. This is required both for safe transportation and for the safe use of natural gas. Typical dew points of natural gas in water vary from minus $5^{\circ} \mathrm{C}$ to minus $20{ }^{\circ} \mathrm{C}$ [21], and for hydrocarbons from $0{ }^{\circ} \mathrm{C}$ to minus $10{ }^{\circ} \mathrm{C}$ [22].

In order to comply with these requirements, it is necessary to remove water and a fraction of $66+$ hydrocarbons from gas.

\section{Conclusions}

The analysis of methods to reduce energy consumption during the transportation of natural gas through pipelines is done.

It is shown that lowering the gas temperature before compression also leads to a decrease in the work spent on gas compression, and cooling tasks can be solved most energetically efficiently using heat-consuming AWRM s with a wide range of cooling temperatures, which use the thermal energy of the exhaust gases for their work.

To assess the prospects of pre-cooling the process gas before compression, the working parameters of a typical gas pumping unit are calculated and, based on the analysis of the calculation results, the energy and financial prospects of such a solution are shown. So, for example, for the current economic situation (July 2019) in the Ukrainian gas market, the daily decrease in operating costs in standard gas pipelines with a decrease in gas temperature before compression in the gas pumping unit by $20 \mathrm{~K}$ ranges from 1800 USD to 3360 USD.

To implement the technology for pre-cooling the process gas, an original design of an AWRM-based heat recovery plant has been proposed, which in the range of typical operating characteristics allows to reduce the temperature of the process natural gas before compression by $11 \ldots 13{ }^{\circ} \mathrm{C}$.

The technology for pre-cooling the process gas allows to reduce the temperature level of the compressed gas and to obtain an additional economic effect due to the ACA shutdown, which can be estimated for specific climatic conditions in the region where the compressor station is located.

\section{References}

[1] Serediuk, M. D. (2002). Proektuvannia ta ekspluatatsiya naftoproduktoprovodiv. Ivano-Frankivsk: IFNTUNH, 282.

[2] Govdiak, R. M. (2012). The Increase of Energy and Ecology Efficiency of the Main Gas Pipelines Functioning. Energotehnologii i resursosberezhenie, 3, 56-62. Available at: http://nbuv.gov.ua/UJRN/ETRS_2012_3_11

[3] MShU "Skolkovo": ODIN GOD DO CHASA «Ch»: v poiskah kompromissa po ukrainskomu gazovomu tranzitu. Available at: https://nangs.org/analytics/mshu-skolkovo-odin-god-do-chasa-ch-v-poiskakh-kompromissa-po-ukrainskomu-gazovomutranzitu-dekabr-2018-pdf

[4] Dombrovskiy, A., Unigovskiy, L. GTS: vremya ne zhdet. Available at: https://zn.ua/energy_market/gts-vremya-ne-zhdet-276983_html

[5] Kirillin, V. A., Sychev, V. V., Sheyndlin, A. E. (2008). Tehnicheskaya termodinamika. Moscow: Izdatel'stvo MEI, 496.

[6] Influence of Ambient Temperature Conditions. Main engine operation of MAN B\&W two-stroke engines (2010). MAN Diesel \& Turbo, Copenhagen, Denmark, 17.

[7] Radchenko, A. N., Konovalov, D. V. (2011). Resursosberegayushchaya teploispol'zuyushchaya ustanovka konditsionirovaniya vozduha na vhode dizelya transportnogo sudna. Aviatsionno-kosmicheskaya tehnika i tehnologiya, 5, 61-67.

[8] Radchenko, R. N., Bogdanov, N. S., Shcherbak, Yu. G. (2016). Ohlazhdenie nadduvochnogo vozduha malooborotnogo dizelya $\mathrm{s}$ ispol'zovaniem ego tepla. Kompressornoe i ehnergeticheskoe mashinostroenie, 1 (43), 35-39.

[9] Morozyuk, T. V. (2006). Teoriya holodil'nyh mashin i teplovyh nasosov. Odessa: Studiya «Negotsiant», 712. 
[10] Titlov, A. S., Sagala, T. A., Artyuh, V. N., D'yachenko, T. V. (2017). Analiz perspektiv ispol'zovaniya paroehzhektornoy i absorbtsionnoy holodil'nyh ustanovok dlya ohlazhdeniya tehnologicheskogo gaza i polucheniya zhidkogo uglevodorodnogo topliva. Kholodylna tekhnika ta tekhnolohiya, 53 (6), 11-18. doi: https://doi.org/10.15673/ret.v53i6.920

[11] Uchida, S., Nishiguchi, A. (2006). Low temperature absorption refrigeration machine with water-LiBr mixed refrigerant. Int. J. Refrigeration, 81 (946), 618-621.

[12] Baranenko, A. V., Posylin, D. N., Malinina, O. S. (2017). Performance of single-stage absorption lithium bromide refrigerating machine at boiling points below 0 oC. Journal International Academy of Refrigeration, 16 (4), 52-58. doi: https://doi.org/ 10.21047/1606-4313-2017-16-4-52-58

[13] Galimova, L. V. (1997). Absorbtsionnye holodil'nye mashiny i teplovye nasosy. Astrahan': Izd-vo AGTU, 226.

[14] Postanova Natsionalnoi komisiyi, shcho zdiysniuie derzhavne rehuliuvannia u sfer enerhetyky ta komunalnykh posluh. 30.09.2015. No. 2494. Zareiestrovano v Ministerstvi yustytsiyi Ukrainy 6 lystopada 2015 r., No. 1379/27824.

[15] Kopey, B. V., Bellauar, A., Abdel'baki, N. (2009). Nadezhnost' gazoperekachivayushchih agregatov s tsentrobezhnym nagnetatelem RF-2BB-30 “KUPER-BESSEMER”. Naukovyi visnyk IFNTUNH, 3 (21), 92-98.

[16] Naftogaz v iyule snizhaet tsenu gaza dlya promyshlennosti v srednem na $13 \%$. Available at: https://www.ukrinform.ru/rubric-economy/2725454-naftogaz-v-iule-snizaet-cenu-gaza-dla-promyslennosti-v-srednem-na-13.html

[17] Osadchuk, E. A., Titlov, A. S., Kuzakon', V. M., Shlapak, G. V. (2015). Development of schemes of pump and gasoline-pump absorption water-ammonia refrigeration machines to work in a system of water production from the air. Technology Audit and Production Reserves, 3 (3 (23)), 30-37. doi: https://doi.org/10.15587/2312-8372.2015.44139

[18] Morozyuk, T. V. (2006). Teoriya holodil'nyh mashin i teplovyh nasosov. Odessa: Studiya «Negotsiant», 712.

[19] Sorogin, F. G. (2017). Metod rascheta ehnergeticheskih pokzateley GTP. Vestnik dvigatelestroeniya, 2, 29-33.

[20] Absorbtsionnye vodoammiachnye holodil'nye mashiny. Available at: http://www.stroitelstvo-new.ru/holodilnye-ustanovki/ absorbcionnye-vodoammiachnye.shtml

[21] GOST R 53763-2009. Gazy goryuchie prirodnye. Opredelenie temperatury tochki rosy po vode (2010). Moscow: Standartinform, 39 .

[22] GOST R 53762-2009. Gazy goryuchie prirodnye. Opredelenie temperatury tochki rosy po uglevodorodam (2010). Moscow: Standartinform, 15 . 